\title{
ROLE OF ENGINEERING EDUCATION IN NIGERIAN ECONOMIC DEVELOPMENT
}

\author{
Ekpobodo Ovwigho Raymond (Phd Student) \\ Peoples' Friendship University of Russia Engineering business and \\ enterprise management department
}

Doi: 10.19044/elp.v1no1a9 URL:http://dx.doi.org/10.19044/elp.v1no1a9

\begin{abstract}
This article examines engineering education as an economic development of global society and how these themes can impact on a country economic growth. The central issue of this article is the argument that engineering education changes global environment and it will increasingly depend on a country's ability to understand the role of human capital. The article further describes the importance uses of engineering education and knowledge technology in appropriate ways for development of a country. This article continues to express the influence of knowledge in development of regional economic growth. The article also presents a revision of economic growth theories that are fully related to the Engineering Education for a country to be considered.
\end{abstract}

Keywords: engineering education, economic development, knowledge.

\section{Introduction}

Nigeria as the most populous country in Africa and number seven world rated population nation with over more than one hundred and seventy million people $(170,000,000)$ has big advantage to provide its economic growth through engineering education because changes in the global environment require changes in engineering education. The general conception of investment in human capital originated not long ago. It's the government, marketers, companies, private organization and individuals that can make this changes happened. Spending on human capital through standard engineering education is the best value a country can enrich his economic development. Development is the driving engine of environment, economy and society. Counting on this fact, basic engineering skills such as knowledge of the engineering fundamentals and technologies have become commodities that can be provided through lower cost of engineers in many developed and developing countries. As the world is upgrading every 
seconds of today-today; many countries look forward for better alternative to strengthen their economic growth. Base on this conception, Nigeria has found itself among states that need engineering education to improve their economic growth. Engineering education play a key role of sustainable economy development of any country. Engineers do make the society look real life and glamour. Therefore, the Government of Nigeria investing in engineering education, it's a good investment any country can think of because human capital long-life return will contribute to the labor market and not only that but also to create jobs opportunity for individuals; human empowerment and will impact on the economic development of the entire nation and finally, it will make their engineers proceed and sell in the global market.

\section{Engineering education}

The notion of engineering education is to prepare students broadly knowledge of new technology through engineering skills profession. Engineers are visional people who create things by making use of technology to integrate our environment and developing oneself and other. Engineering education simultaneously play an active role and contribute to sustainable development by creating learning environments for students. Therefore, there is nothing more fundamental to the future of a nation engineer's enterprise that the notion of attracting talented young men and women to acquire engineering degree and providing them with an educated adopted for the apparent and future society. The impact of engineering education on economic growth, it always remind me the opinion of the engineering profession by the great Theodore Von Karman when he quoted, "Scientists study the world as it is; while engineers create the world that has never been."

This fantastic opinion of Theodore Von Karman was also illustrated with this simple diagram shown below. 


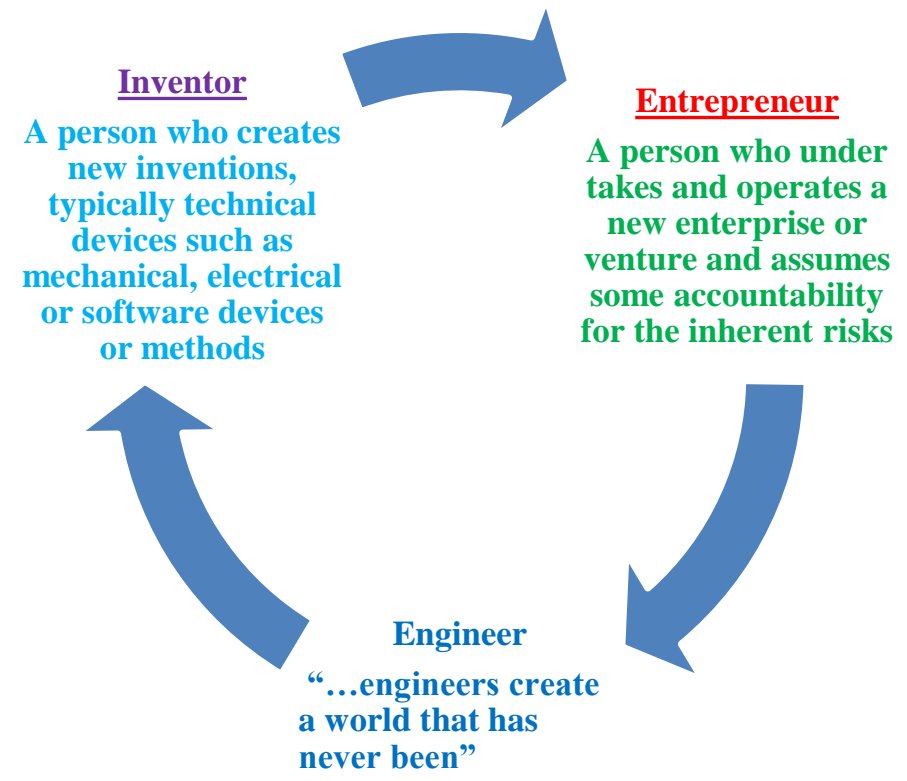

Sources: Wikipedia, Theodore Von Karman, 2008.

Considering this brilliant conception, it is very obvious that with proper teamwork, leadership and social awareness and not only but also domain specific-knowledge and experiences; an engineer can knows how things work and what customers want through integration of general engineering skills. The creative aspect of it, they can determine whether customer value and enterprise value are business sense.

There will be always competition in the global economy market among the developed and developing countries because every leader want her country to be seen as the best economic growth in the world. Hence, engineering education will continue to play a vital role in economic development. This remind me of Dubai a city in United Emirate were infrastructures constructed by engineers have transformed the entire city to business center with multinational companies and tourist coming in every day. This has create jobs opportunity and reduces unemployment rates and brought in sustainable economy development into the entire state. As Nigeria population increases every day, there is need of well-prepared engineers that can create and develop products and system that will improve safety and quality of people life for change of environment. Considering all these fact, Nigeria as a nation has to wake up and take drastic creative ideas to reform their engineering education because the global market of engineers will 
continue to need competence engineer graduates and skills technology with new innovative and creative ideas to build our present and future society.

Economic growth and human capital:

The idea of engineering education is the main factor of this article. As a capital good is generated from the concept of "human capital" that requires a high quality of human skills to obtain development. Human skills are as important in productive input of development process of natural wealth. Since engineering education play an active role in both creation and improvement of human capital, its relevance and importance to economic growth and development. According to Jhinagan (2005), the process of economic growth is traditionally practice to include more importance to absorb physical capital to human capital.

The best investment a country or government can give to his people, is to give them quality engineering education. This means you are teaching them how to fish but not giving them fish only. Indirectly, human capital contribute to growth productivity and employment; and for this to happen, its require knowledge based, skill, and talented of other workers. According to the concept of Schumpeter has in mind when he describe "by 'development' therefore, we shall understand only such changes in economic life as are not forced upon it from without but rise by its own initiative from within" (quoted in Higgins, 1968, p. 93). With this description of Schumpeter, Spending money on engineering education as part of human investment will massively yield the country human capital long-life return of knowledge based and this will influence on the development of the regional economic growth and create jobs for unemployment people. According to the theory observes education and training as a key factor of human resources and development that influences economic growth. It was described by Schultz (1971) in his own conceptual opinion that say: The most distinct feature of our economic system is the growth in human capital. Without it, there would be only hard, manual work and poverty except for those who have income from property. (Schultz, 1971, p. 47). The originating of new growth theories are therefore significant in the introduction of the active role of human capital in the growth of economies. According to the Spillovers theory of technology, the economic growth and income of many countries as country productivity depend on the available important of new technologies and scientific knowledge accumulated and these have create differences among countries in global economic growth market competitiveness as was described by (Eaton and Kortum 2002 and Klenow and Rodriguez-Clare 2005 for reviews).

According to (Todaro and Smith 2003), human capital is the term economists usually use for both education and other human capacities that can raise productivity when increased. Therefore, Engineering and 
technology are the two closely related human capital components that work together to make the individual more productive and develop economic growth of a country per say.

\section{Conclusion}

In conclusion, investing in engineering education and skills technologies will contribute to the economic development and create jobs opportunity for individuals in long term return. As it was argue above, human capital theory describe that individuals develop their capacity to generate incomes and improve career disciplines through education and skills training in reproduction of economic development. Engineering education stimulate importance role in the knowledge based society because the knowledge and human capital generated by engineering education they drastically changes the economic development. The productivity of human capital in knowledge growth influence regional economic growth. Therefore, the effective output of growth and economic development would be even more pronounced than the pronounced entrepreneurs apply and disseminate the knowledge in a region. There is need for changes to be made in the Nigeria engineering education is conceived and delivered to enable engineering graduates to fit in the global sustainable development and also to make impact in the economic growth. Promotion of engineering education standard in Nigeria will drastically increase returns to human capital in knowledge growth and create opportunity for young engineers to sell in the global labor market.

\section{References:}

Crawley, E. F., Malmqvist, J., Östlund,, S., \& Brodeur, D. R., Rethinking Engineering Education: The CDIO Approach, Springer, New York, 2007. "Innovation: Is Global the Way Forward?" Joint study, Booz Allen Hamilton and INSEAD. Available at http://www.boozallen.com/media/file/ Innovation_Is_Global_The_Way_Forward_v2.pdf.

The Royal Academy for Engineering (2005). Engineering for Sustainable Development: Guiding Principles. The Royal Academy for Engineering: London.

Todaro, Michael P. and Smith, Stephen C. Economic Development. Pearson Education Limited, 2003.

The Journal of Engineering Education, Special Issue: The Art and Science of Engineering Education Research, January 2005.

Shaver, Kelly G., 2003, "The Social Psychology of Entrepreneurial Behviour," in Zoltan J. Acs and David B. Audretsch (eds.), Handbook of Entrepreneurship Research, New York: Kluwer, pp. 331-358. 
Higgins, B. (1968). Economic development: Problems, principles and policies (Rev. ed.). New York: Norton.

Bottazzi L. and Peri G. (2003) Innovation and spillovers in regions: evidence from European patent data, European Economic Review 47, 687-710.

Baumol, William. 2005. "Entrepreneurial Enterprises, Large Established Firms and Other Components of the Free-market Growth Machine." Small Business Economics, 23(1), 9-21.

Walker, I., \& Zhu, Y. (2003). Education, Earnings and Productivity: Recent UK Evidence. Labour Market Trends, 111(March), 145-152.

Segalàs J., Ferrer-Balas D., Mulder K. Pedagogical strategies for learning sustainability by engineering students. Proceedings. EESD, 2008. 